\title{
K ÚLOZE TEORIE V SOCIOLOGICKÉM VÝZKUMU
}

Prof. ing. FRANTIŠEK ZICH, CSc.

Pojetí marxistické sociologie předpokládá její aktivní úlohu ve společenském životě, v řizení sociálních procesů. Mají-li být úkoly tohoto druhu plněny, je nezbytné věnovat systematickou pozornost komplexnímu rovoji této vědy. Co znamená tento komplexní rozvoj? Jde o harmonické prohlubování všech relativně samostatných oblastí sociologie, tj. její teoretické, metodologické i metodické výzbroje. Způsob provádění sociologické badatelské činnosti v současném období $\mathrm{v}$ našich podmínkách podle mého soudu takovouto komplexnost citelně postrádá. Zaostává zejména rozvoj teoretických složek výstavby této vědy a stále př́liš jednostranně se rozvíjí empirický výzkum. Tím se komplikuje slučitelnost teoretických postulátů se závěry a poznatky.z empirických výzkumů a spolu s tím roste obtižnost využívání těchto poznatků v řídicí praxi. Problémy využitelnosti pramení podle mého soudu hlavně právě z faktické nepropojenosti teorie marxistické sociologie a konkrétních poznávacích procesů $\mathrm{v}$ rámci sociologických výzkumů. Tato situace je vážná a je možno říci, že se nezlepšuje, i když u nás i v jiných socialistických zemích byla publikována již řada metodologických prací, zdůrazňujících význam dialektické jednoty teoretických a empirických složek poznání v sociologii. Byla provedena kritika empirismu, rozpracovány a formulovány principy materialistické dialektiky, jež musí být respektovány $\mathrm{v}$ procesu sociologického výzkumu, setkáváme se s články, které zdůrazňují význam sociologického poznání pro společenskou praxi atd. Většina $z$ těchto prací však je zatím vedena ve značně obecném duchu, v lepším př́ípadě v rovině stanovení pravidel, principů postupů, ale stále chybí hlubší rozpracování obsahově teoretických základů a kritická metodologická analýza výzkumné praxe.

$\mathrm{V}$ této stati jde o naznačení hlavních problémů, jež by podle mého soudu měly být $\mathrm{v}$ sociologické metodologii řešeny $\mathrm{z}$ hlediska úlohy teoretické složky poznání. Stat' je chápána jako př́spěvek do diskuse o problematice vztahu teoretické a empirické složky poznání v marxistické sociologii. Vychází z předpokladu nezbytnosti neustálého dialektického pronikání obou složek poznání 
a přesvědčení autora, že $v$ současné etapě je nedoceňována především úloha teorie $v$ tomto procesu. Je pokusem identifikovat některé problémy zatím nedostatečného využívání obecně teoretického metodologického základu marxismu v sociologii a naznačit možné postupy dalšího rozvoje metodologické vybavenosti této vědy.

\section{TEORETICKO-LOGICKÁ METODA V SOCIOLOGICKÉM VÝZKUMU}

Práce zabývající se úlohou teorie v sociologickém výzkumu zdůrazňují její význam jako určitého východiska poznávacího procesu. Teorie je chápána především jako kumulované poznání o zkoumaném problému, jež je v daný moment $\mathrm{k}$ dispozici, př́padně jako součást obecnější teoretické koncepce. Existence takovéto obecné koncepce př́islušné oblasti společenského pohybu umožňuje pro poznání jí př́slušných problémů formulovat výchozí hypotetické předpoklady. Spolu s tím je pro daný problém vytvářen relevantní konceptuální rámec jako východisko pro empirickou fázi výzkumu. V metodologických direktivách pro provádění sociologických výzkumů je tento př́ístup formulován jako „teoretická analýza“ problému, na kterou pak navazuje etapa tvorby relevantních hypotéz, jež mají být v dalších krocích výzkumu verifikovány prostřednictvím shromáždění a vyhodnocení příslušných dat. Takovýto postup je možno $\mathrm{z}$ hlediska logiky poznávacího postupu pokládat za správný. Je předpokladem racionálního a smysluplného využití poznávacích metod (vlastně také celé použité výzkumné, materiálové, lidské apod. kapacity), nebot' zajišt'u je zaměrení poznávací činnosti na takové nepoznané aspekty zkoumaného problému, které jsou nejzajímavější a nejvyužitelnější v praxi.

$\mathrm{V}$ naší metodologické literatuře je této problematice věnována poměrně značná pozornost. ${ }^{1}$ ) Je však možno říci, že v těchto pracích má rozbor významu teorie v sociologickém výzkumu poněkud abstraktní charakter. Zdůrazňuje se význam teorie jako východiska poznání, stanovují se určitá pravidla a schémata postupu tvorby hypotéz, uvádí se jejich třídění a druhy, avšak v celém zřetelně chybí rozpracování obecných vědních metod, zejména pak historické a logické metody. To se projevuje i v praxi provádění sociologických výzkumů. Výzkumy mají většinou pouze popisný charakter, nepronikají hlouběji $k$ podstatě problému, což má negativní vliv na jejich využitelnost v praxi. Je třeba podle mého soudu proto věnovat mnohem větší pozornost používání logické metody, a to zejména v př́pravné fázi sociologického výzkumu. Logická metoda není vlast-

1) Viz např. práce M. Katriaka, A. Hirnera, F. Zicha a dalších autorů. 
ní jen tzv. teoretickým disciplínám, jak se někdy uvádí, ${ }^{2}$ ) ale má univerzální platnost pro veškeré vědecké poznání. Nejobecnější teoreticko-logickou metodou všech věd je materialistická dialektika. K. Marx rozpracoval a použil tuto metodu zejména ve svém díle Kapitál. Vyšel přitom jak známo z tvůrčího rozpracování postupu od abstraktního ke konkrétnímu, jak jej předložil G. F. Hegel. Marx však překonal idealismus obsažený $v$ Hegelově přístupu. „Hegel totiž nechápal postup od abstraktního ke konkrétnímu jako způsob teoretického zobrazení objektivní skutečnosti, ale jako formu její tvorby logickou ideou“. ${ }^{3}$ ) Tím také Marx povýšil logickou metodu na metodu umožňující vytvářet vědecké teorie použitelné ve společenské praxi. Logická metoda je důležitý nástroj v současném rozvoji vědeckých teorií.

Má-li věda vysvětlit fakt existence a vývoje určitého objektu, odhalit př́slušnou zákonitost tohoto vývoje, nemůže stavět své poznání jen na jevových stránkách (zdánlivém, zjevném pohybu). Naopak, musí v určité fázi od těchto jevovvých stránek abstrahovat. $K$ vysvětlení věci tedy nemůže věda přistoupit najednou. Takovýto přístup je výsadou i rizikem jen běžného každodenního poznání. Vědecké poznání představuje naproti tomu složitý proces, v němž se uplatňuje abstrakce i konkretizace v nepřetržitém dialektickém sledu a jednotě. Abstraktní vzniká ze smyslově konkrétního vnímání určitého reálného celku. Toto smyslově konkrétní však postihuje př́íslušný celek neúplně a jednostranně. Proto i tato prvá abstrakce je neúplná a jednostranná. Sama realita (př́íslušný celek) není postižena a vyčerpána jen tím, co vidíme, slyšíme atd. a co si o této realitě představujeme (tedy ani ne tím, jak nám odpovídá respondent na otázky o př́slušném celku, jevu), ale obsahuje i to, co je za těmito vjemy a představami této úrovně vnímání reality skryto. K čemu se lidské poznání může dostat právě jen v pojmech, zákonech a teoriích. To znamená, že abstrakce vzniklá ze smyslově konkrétního musí být upřesňována, což v metodě výzkumu znamená přejít od abstraktního k myšlenkově (teoreticky) konkrétnímu. Cesta od abstraktního k myšlenkově konkrétnímu je tak v každé etapě společensko-vědního poznání zák onitým předpokladem jeho rozvoje a časového i věcného relativního završení.

Vědecký výzkum nelze tedy realizovat, není-li v jeho procesu zahrnuta logická metoda. V našem sociologickém výzkumném myšlení však je stále př́liš rozšířeno jednostranné jen „induktivni“ myšlení. Přitom složitost problémů, jež jsou předmětem zkoumání nemůže být fakticky postižena ani jen induktivními, ale ani jen deduktivními postupy. Oba představují pouze dílčí metody, jejichž způsob použití $\mathrm{v}$ dialektice poznávacího procesu závisí na cílech poznání

$\left.{ }^{2}\right)$ Viz např. I. Hrůza: K problematice dalšího rozvoje teorie vědeckého komunismu. Sociologický časopis, č. 2, 1981 .

$\left.{ }^{3}\right)$ V. Cerník: Problém zákona v marxistickej metodológii vied. Bratislava, Pravda 1977, s. 167. 
a konkrétně historických podmínkách stavu a rozvoje zkoumaného předmětu. Přeceňování induktivních metod, dokonce jako hlavních metod tvorby sociologických teorií je v současné etapě rozvoje marxistické sociologie nezdůvodněným anachronismem.

Úkoly poznávacího procesu, plynoucí z nezbytnosti aplikace logické metody nejsou v sociologické výzkumné praxi vyčerpány a splněny ani postupem dekompozice, či operacionalizace výchozích pojmů. Tyto operace představují v podstatě jednostrannou strukturální analýzu obsahu př́íslušného pojmu, která je zaměřena hlavně na stanovení vlastností, rysů, charakteristik ap., jež mají být empiricky zjištovány. Jde tedy především o vytvoření předpokladů k dalšímu postupu konkretizace abstraktního, nikoliv však o konkretizaci samu. Operacionalizace a dekompozice předpokládá následnou syntézu, na jejímž základě je možno upřesnit konkrétní obsah pojmů. Syntetizující postupy jsou však v naší sociologické výzkumné práci dosti málo používány, na rozdíl od analytických metod jsou i nedostatečně teoreticko-metodologicky objasněny.

Určitý schematismus a rutinérství, které se projevují v běžných sociologických výzkumech u nás, nenachází svůj výraz jen ve zdůvodňování induktivních postupů, ale právě i v nedoceňování logické metody. Realizace postupu od abstraktního ke konkrétnímu ve vědě předpokládá určitou teorii společenské reality, jež zahrnuje i sít' výchozích a základních pojmů. Vědecké pojmy jsou vždy prvky určitého celku, určitého teoretického přístupu a postihování jedné oblasti skutečnosti. „V složité síti vědeckých pojmů lze rozlišit tři specifické okruhy pojmů: speciálně vědní, obecně vědní a filozofické. Přitom hovoříme-li o filozofických pojmech, nemáme na mysli pojmy jakékoliv filozofie, ale pojmy vědecké filozofie, dialektického a historického materialismu“ “. ${ }^{4}$ )

V sociologii u nás se někdy setkáváme s názorem, že nemáme dostatečně rozvinutou sociologickou teorii, nebo že ji dokonce nemáme vůbec. Domníváme se, že takovéto názory jsou jen částečně opodstatněné. Existuje především nejobecnější marxistická sociologická teorie - historický materialismus, který postihuje základní podstatné zákonitosti existence a vývoje lidské společnosti. Je proto východiskem pro každý výzkum, a to nejen z metodologického hlediska, ale i z hlediska obsahového. Při zkoumání relativně samostatných sociálních procesů (objektů, problémů) však skutečně nemusí být a také často není po ruce dostatečně konzistentní teorie či alespoň výchozí soustava zdůvodněných pojmů relevantních předmětu výzkumu. Právě však v těchto případech se ve zpracovávání výchozích koncepcí výzkumu především musí uplatňovat obecnější, tj. obecně vědní a filozofické pojmy a teorie (teoretické modely reality).

$\left.{ }^{4}\right)$ J. Stachová: K otázkám vztahu speciálně vědních, obecně vědních a filozofických pojmů a kategorií. In: Dialektika a systémový prístup. Svoboda 1979, s. 120. 
Obecnost těchto pojmů a jejich systém (teorie) umožňuje identifikovat na úrovni hypotéz podstatné souvislosti zkoumaného procesu (objektu, problému). Předpokládáme tedy, že obecná teorie zahrnuje zákony, jež umožňují formulovat určité závěry (hypotetického charakteru) o třídách objektů (systémů, procesů, jevů) nižší roviny složitosti. Postup vytváření hypotetických závěrů o celcích nižších rovin a jejich postupné ověřování je také jedním z postupů konkretizace nejobecnějších a obecných pojmů (přechodu od abstraktního ke konkrétnímu), tedy upřesňováním jejich obsahu, upřesňováním celé teorie a současně i procesem tvorby pojmů nových.

Současný stav rozvoje marxistické vědy umožňuje prakticky na všech stupních obecnosti zkoumaných celků $v$ té či oné míře uplatňovat logickou metodu. Postup od abstraktního ke konkrétnímu je $\mathrm{v}$ současné vědě možný především proto, že existují abstraktní (pojmová) určení většiny příslušných reálných sociálních celků, jež jsou předmětem nového výzkumného zájmu. K stanovení těchto abstrakcí vedla složitá cesta předcházejícího poznání a jeho spojování s praktickou činností lidí. Je proto možno říci, že pojmy vědy nejsou prostou idealizací smyslově konkrétního poznání, ale že obsahují vždy současně vyšší či nižší stupeň myšlenkově konkrétního. Zahrnují tedy i historický (vývojový) aspekt pohybu př́slušného celku a vždy i určitý stupeň potvrzení své pravdivosti. Logická metoda $\mathrm{v}$ tomto použití je nástrojem vyjádření konkrétně historicky podmíněného obsahu pojmů a poznání vývoje př́ślušného objektu (systému, jevu) jež zobrazuje i nástrojem zachování kontinuity poznání.

Cílem současných výzkumů většinou není (snad jen výjimečně) hledání zcela nových označení pro jevy objektivní skutečnosti, nových pojmů, ale upřesñování a prohlubování jejich obsahu v souladu s vývojem zobrazovaných objektů a jejich systémů a $\mathrm{v}$ souladu $\mathrm{s}$ procesem prohlubování vědeckého poznání. Logická metoda proto nevystupuje ve vědě izolovaně, nebo jen jako jednorázová akce, ale je fakticky imanentní metodou poznávacího procesu, postihující neustálý pohyb od abstraktního určení ke konkrétnímu a odtud k hlubší abstrakci a dále $\mathrm{k}$ hlubšímu konkrétnímu určení, atd., atd. Jen touto cestou si lidé vytvářejí také možnosti vstupovat cílevědomě do ř́zení objektivních procesů.

Naznačený postup konkretizace abstraktních určení reálných celků je jen první „etapou“ v realizaci logické metody. Je to vlastně objasnění podstaty tohoto celku, jeho vnitřních zákonitých souvislostí a „vnitřního“ pohybu. Není třeba jistě zdůrazňovat, že tento „vnitřní“ pohyb se liší od pohybu celku jako takového. Existence celku je rozpornou jednotou „vnějš́ího“ (zjevného) i ,vnitřního“ pohybu. Vědecký výzkum v této etapě použití logické metody tedy usiluje o odhalení, či upřesnění podstaty reálných celků, objektů, vztahů ap., jež jsou vyjádřeny př́ślušným pojmem. Zde je možno uvést výstižnou charakte- 
ristiku poznání V. I. Lenina: „Myšlení postupující od konkrétního k abstraktnímu nevzdaluje se, je-li správné (NB) ... od pravdy, ale přibližuje se $\mathrm{k}$ ní ... všechny vědecké ... abstrakce odrážejí př́írodu hlouběji, věrněji, úplněji““.5) Vědecká abstrakce je postupně upřesňována v procesu její konkretizace. Logická metoda v Marxově rozpracování má však ještě další a je možno říci, že podstatnou ,etapu““. Je to cesta poznání od podstaty $\mathrm{k}$ „,buňce“ (k ,jádru")). Vědecky zdůvodněné a určené podstaty reálných celků vytváŕí složitý systém v souladu s existencí objektivně existujícího systému obecnějšího celku. Jednotlivé pojmy (podstaty) vždy samy o sobě postihují tento vyšší reálný celek pouze parciálně. Jsou nástrojem vysvětlení podstaty a vzájemné souvislosti relevantních částí tohoto celku. Postihnout pohyb a podstatu vyššího celku (a analogicky každého celku) znamená odhalit vývoj jeho základu, což znamená odhalit vznik a proces rozvoje jeho „genetické struktury“. $\mathrm{K}$ tomu je třeba $\mathrm{v}$ myšlení předběžně zredukovat tuto genetickou strukturu na její zárodečnou formu, na vztah, z kterého se historicky a logicky vyvinula. ${ }^{6}$ )

Odhalení „zárodečné formy“ celku (objektu) představuje zásadní metodický krok od smyslově konkrétního k abstraktnímu. Metodicky jde o analýzu jevových struktur. Je současně předpokladem a východiskem realizace poznávaného procesu od abstraktního $\mathrm{k}$ myšlenkově (teoreticky) konkrétnímu. To znamená, že od „zárodečné formy“ ( „,buňky“) určitého celku (abstrakce) přecházíme zpět $\mathrm{k}$ objasnění konkrétní podstaty celku. Cesta od této „podstaty podstat" k podstatě obsahuje odhalení jeho vnitřní genetické struktury. Jde o syntetické procesy myšlení, které směřuje k vytvoření „teorie“ celku. Celek není již vyjádřený pouze jedním pojmem, podstatnou abstrakcí, ale je deduktivně rozvinutou formou této abstrakce. Dosahujeme tak rozvětveného poznání zkoumaného celku s odhalením imanentního zákona jeho existence. Pro tuto teorii celku však platí, že nepostihuje celek v celé jeho realitě, ve všech projevech jeho existence. „.. . úplná teorie „,buňky“ je neúplnou teorií vyvinutého celku; sama „,buňka“ je objektivně jen abstraktní možností vyvinutého celku“ ${ }^{7}$ ) Nicméně vyvinutá teorie určitého celku (objektu) nám umožňuje explanaci projevů jeho existence. Tím, že teorie obsahuje imanentní zákon jeho existence, lze rovněž predikovat vývin celků i jejich modifikaci v podobě různých projevů.

Takto pojata logická metoda ve vědecké praxi je cestou, jak překonat omezenost zjišt'ování jen jevových souvislostí, což je běžné v dosavadní praxi sociologických výzkumů a předpokládá posun cílů výzkumu k odhalení zákonitostí vývoje př́ślušných jevů.

Je třeba patrně odpovědět na otázku, proč se logická metoda v této rozvinuté

5) V. I. Lenin: Spisy sv. 38. Praha 1960, s. 179.

$\left.{ }^{6}\right)$ V. Cerník: Problém zákona v marxistickej metodológii vied. Bratislava 1977, s. 180.

$\left.{ }^{7}\right) \mathrm{Viz}$ V. Cerník, c. d. s. 186. 
podobě (obsahující oba kroky - př́padně ještě prediktivní krok) v sociologickém výzkumu málo používá. Většinou jde ve výzkumech pouze o snahu poznat podstatu jevu, nebo jen, a to častěji o analýzu projevu podstatných souvislostí. V žádném př́ípadě však o odhalování „,podstaty podstat“, tj. o poznání základních genetických struktur jevů (celků, objektů). Podle mého soudu to plyne jednak $\mathrm{z}$ jednostranného chápání sociologického výzkumu jen jako empirické akce, $\mathrm{z}$ nedoceňování syntetických a teoretických metod $\mathrm{v}$ této vědě a jednak $\mathrm{z}$ faktické obtížnosti této metody vzhledem $\mathrm{k}$ celkovému stupni rozpracovanosti vědecké metodologie.

Vezměme například problematiku výzkumu třídní sociální struktury socialistické společnosti. Metodika výzkumu provedeného v ČSSR v roce 1978 je zaměřena na odhalení vývojových změn, ke kterým došlo během sedmdesátých let. ${ }^{8}$ ) Tato metodika přes řadu zajímavých přístupů v podstatě odpovídá tradičně statisticko-strukturální metodě popisu stavu a z něj odvozené změny. Výsledky jsou bezesporu zajímavé, obohatily naši poznatkovou bázi o poznání vývoje tř́ině sociální struktury naší společnosti a jsou využitelné v praxi. Výzkum však zatím neumožnil dostatečně hluboce odhalit působení obecných zákonů vývoje sociální struktury společnosti v etapě budované rozvinuté socialistické společnosti, nebot' se těchto zákonitostí dotýká jen $\mathrm{v}$ jevové a faktuální rovině. Data a $\mathrm{z}$ nich odvozené poznatky jsou ve vztahu $\mathrm{k}$ obecné teorii tř́íd - v této etapě zatím - spíše ,ilustračním“ materiálem než nástrojem konkretizace a rozvoje této teorie. Jsou více či méně výstižným ukazatelem stavu a mnohem méně umožňují postihnout dynamiku celého vývoje. Rozvoj teorie $v$ této oblasti zřejmě $\mathrm{v}$ dalším kroku proto vyžaduje použití logické metody (a dále i metody genetickohistorické spolu s další hlubokou analýzou empirických dat). Má-li být odkryta zákonitost vývoje tř́ídně sociální struktury v socialistických podmínkách, je třeba zkoumat nejen jevové změny v této struktuře, ale také jejich přičiny spočívající v základech celospolečenského vývoje. To znamená, že je nezbytné najít „genetickou strukturu“ podstaty tříd za socialismu, tj. základní „buňku“ jejich existence a vývoje. K poznání této genetické struktury nevede patrně pouze deduktivní cesta charakteristická pro současný rozvoj oboru vědecký komunismus u nás. Výzkum zákonitostí formování tř́íní struktury v socialistických podmínkách musí vycházet z Marxova objevu podstaty kapitalistické společnosti, z objevu kategorie hodnoty, jež je onou základní „buňkou“ uspořádání sociální struktury (ale i ekonomických a nadstavbových institucí) této společnosti. $\mathrm{Z}$ této základní „,buňky“ je možné dále deduktivně odvodit základní „,buňky“ nižších sociálních celků (podsystémů), tj. v tomto pří-

8) Metodika výzkumu třídní a sociální struktury CSSR 1978, interní tisk ÚFS CSAV Praha 1979. 
padě podstatu tř́́dní diferenciace $\mathrm{v}$ kapitalistické společnosti, kterou je vlastnictví výrobních prostředků. $Z$ této základní „buňky“ je odvozena genetická struktura tř́ídně-sociálního uspořádání kapitalistické společnosti a také teorie tříd a třídního boje. Teorie založená na tomto základním vztahu je však mnohem širší, zahrnuje například i určení dalších znaků, strukturních vztahů apod. (Viz definice tř́íd V. I. Lenina.)

V současných výrobních vztazích, které jsou výsledkem revoluční přeměny společnosti, platí teorie tříd $\mathrm{v}$ souladu se známými podmínkami v konkrétně historicky modifikované podobě. Již podle vnějších jevových poznatků můžeme konstatovat, že tyto třídy mají zcela jiný charakter, a tím i vztahy mezi těmito třídami jsou zásadně odlišné od podmínek kapitalistické společnosti.

Máme-li však odpovědět na otázku, jaký bude další vývoj těchto tříd dostatečně konkrétně, musíme konstituovat ucelenou teoretickou koncepci tříd pro socialistické podmínky. Pro vědecký výzkum to stručně řečeno znamená s využitím logické metody postupně odhalit základní „buňku“, na jejímž základě socialistická společnost existuje, funguje, vyvíjí se, tj. musí být odhalena genetická struktura tříd $\mathrm{v}$ socialistických podmínkách.

Úkol tedy spočívá v rozpracování přechodu od podstaty společnosti, již jsou určeny třídy k odhalení jejich ,genetické struktury“ v socialistických podmínkách. Tento úkol nelze realizovat bez: 1 . důsledného uplatnění dialektického materialismu; 2 . důsledného navázání na teorii tříd a třídního boje předcházející etapy vývoje společnosti. Prakticky to znamená, že musí být využity teoretické abstrakce vztahující se $k$ této etapě, nebot' jako vědecké abstrakce $v$ sobě obsahují osvětlení historicko-genetických tendencí; 3. nemohou být realizovány bez konkretizace těchto abstraktních určení prostřednictvím analýzy současných jevů třídní struktury a bez syntetizace výsledků této analýzy.

Důsledná realizace takovýchto postupů vede $\mathrm{k}$ dalšímu myšlenkovému vymezení pojmů třída, třídní struktura, třídní vztahy atd. v socialistické společnosti a k odhalení jejich společného určení, „základní genetické vazby“ základní „buňky“, z níž je možné odvodit teorii socialistických tř́íd: Což je předpoklad pro vysvětlení řady jevů a změn, k nimž dochází v socialistických podmínkách a umožní to i vědeckou predikci pravděpodobného dalšího vývoje apod. Podle mého soudu takto založený výzkum třídně-sociální struktury socialistické společnosti v současné marxistické sociologii chybí. Socialistické třídy, třídní vztahy, skupinové a další vztahy se zjednodušeně vysvětlují pouze extropolací Marxovy teorie tříd, aniž se využívá metodologický aparát i věcný odkaz této teorie. Zjednodušený výklad teorie socialistických tříd se pak nutně musí setkávat $s$ řadou rozporností a redukcí, jež apriory omezují možnosti komplexního ř́zení socialistické společnosti.

Revoluční změny třídně sociální struktury přitom mohou být vysvětleny jen 
na základě historické kontinuity. Jakékoliv abstrahování od této vývojové podmíněnosti vede $\mathrm{k}$ pozitivistickým deformacím poznávacího procesu. $\mathrm{V}$ oblasti výzkumu třídně sociální struktury socialistické společnosti je možné za takovéto deformování pokladat aplikaci stratifikačních koncepcí. Stratifikační koncepce neumožňují odhalit vývojové zákonitosti, nepronikají ke „genetické struktuře“", příčin existence určité sociální diferenciace. $\mathrm{Z}$ hlediska aplikace logické metody představují odhalení pouze jevových, př́ípadně faktuálních zákonů, $\mathrm{v}$ žádném př́padě nejsou stratifikační postupy schopny odhalit imanentní zákony vývoje sociální struktury. Na ústřední pojmy této koncepce (status, vrstva, mobilita) je třeba nahlížet pouze jako na idealizační abstrakce, jež nebyly podrobeny další konkretizaci, tím zůstávají do značné míry neurčitými abstrakty, neumožňujícími hlubší vysvětlení faktu své vlastní existence. Nebo ještě jinými slovy jde o jevová abstrakta, nepostihující reálné sociální celky, ale naopak jsou zde konstruovány celky umělé, podobnostní — jevově odvozené.

Principy materialistické dialektiky vyžadují, aby v souladu se změněnými podmínkami a změnou samotné sociální reality bylo dále rozvíjeno poznání zákonitostí těchto změn, aby mohly být formulovány zákony adekvátní danému vývojovému stupni. Princip historismu a dialektické souvislosti (systémovosti) přitom nesmí být porušen. To znamená, že nové formulace zákonů vyrůstají jako dialektické negace zákonů vývoje předcházejících etap. Nerespektování principu historismu $\mathrm{v}$ badatelské práci vede $\mathrm{k}$ zmíněnému pozitivismu, či koncipování nevědeckých ad hoc teorií na úrovni zjednodušené idealizace jevů, nebo k přebírání nemarxistických teoretických koncepcí, jež většinou jsou právě pozitivistického původu. Výchozí teorie, marxistické pojetí tříd je nástrojem zachování kontinuity poznání a postižení vývoje změněné reality a jejího osvětlení v duchu přísně vědecké dialektické logiky. Jinými slovy, výzkum ,genetické vazby“ (,,buňky“) socialistické třídní struktury je dialektickou negací vědecké teorie tříd, jejím potvrzením a dalším rozvojem.

Některé práce se snaží tuto ,genetickou vazbu“ odhalit v oblasti sociáině ekonomického života společnosti. Za pokusy o její identifikaci můžeme pokládat ty práce, jež usilují o osvětlení úlohy a charakteru dělby práce, obsahu práce za socialismu, úlohy řízení, rozdělování, aktivity lidí, fungování principu kolektivismu apod. Jejich přístup je však zatím značně obecný a současně většinou nekomplexní a nedostatečně syntetizující. Neposkytují dostatečně hluboké zdůvodnění, proč by některý $z$ výše uvedených pojmů mohl vyjadřovat a postihovat základní „genetický vztah“ socialistické třídní struktury.

Jestliže se z hlediska nezbytnosti formovat dostatečně funkční a praktickou teorii socialistických třîd díváme na provedený výzkum třídně-sociální struktury socialistické společnosti, je třeba konstatovat, že jde pouze o prvý krok, jež 
nezbytně musí být následován teoretickou syntézou poznatků. Odhaluje jevové zákonitosti třídní struktury, další postup však vyžaduje důsledné uplatnění teoreticko-logické metody, tj. využití poznatků ke konkretizaci abstraktních určení sociálních skupin $\mathrm{v}$ socialistických podmínkách.

Domnívám se, že tento prríklad výzkumu, který přestože pokročil $\mathrm{v}$ našich podmínkách relativně daleko, dokazuje nezbytnost věnovat větší pozornost teoretické fázi sociologického výzkumu. S pochopením významu proceșuálnosti vědeckého poznání a doceněním logické metody $\mathrm{v}$ naší současné sociologii nemůžeme být spokojeni. Logická metoda představuje nástroj kontinuity poznání, rozvoje teorie i nástroj integrace poznání různých oblastí společenského život. $\mathrm{V}$ neposlední řadě pak působí jako spojující článek mezi teoretickou a empirickou složkou sociologického výzkumu.

Proto má velký význam rozpracování této metody v souladu s jednotlivými kroky sociologického výzkumu. Již bylo uvedeno, že operacionalizace a dekompenzice tento úkol neplní, že je pouze nástrojem konkretizace pojmů, jež však v sociologickém výzkumu v našich současných podmínkách následuje jen nesystematicky. Co tedy znamená uplatnění logické metody v přípravě sociologického výzkumu?

Proces, v němž postupujeme od prvotní abstrakce vzniklé ze smyslově konkrétního $\mathrm{k}$ myšlenkově konkrétnímu je relativně jednoduchý, ale $\mathrm{v}$ současných podmínkách rozvoje vědeckého poznání poměrně vzácný. Ve vědeckém poznávání, jak bylo již uvedeno, jde většinou o uplatnění této metody jako nástroje prohloubení poznání př́slušného objektu. $\mathrm{V}$ tom však existuje také obtížnost uplatňování této metody. Přitom zásadní význam pro prohloubení poznávací hodnoty sociologických výzkumů a hlavně pro posílení možností využívání jejich výsledků v rrídicí praxi, má právě otázka pojmové konkretizace. Většina výchozích teoretických koncepcí v so ciologických výzkumech se vyznačuje neurčitostí základních pojmů a přilišnou povšechností.

Prvý krok logické metody $v$ tomto stadiu výzkumu pak musí být zaměřen na upřesnění těchto pojmů, na jejich obsahovou konkretizaci. Jde především o tyto úkoly:

1. zjistit, nakolik daný pojem postihuje „vnitřní" pohyb objektu celku. Jde o to, není-li konstituován jen na zdánlivém pohybu. Tedy nakolik se přibližuje podstatě existence př́slušného celku a nakolik je vyjádřením pouze jevové zákonitosti;

2. zjistit souvislosti pojmu s ostatními relevantními pojmy teoretického modelu (koncepce) a posoudit, nakolik tyto souvislosti postihují souvislosti objektivní. Vytvořit si pojem nějakého jevu znamená mimo jiné také objasnit jeho místo a úlohu uvnitř konkrétního systému a objasnit ty okolnosti, jež fakticky určují jeho úlohu v rámci celku; 
3. postihnout genezi a historicky daný stupeň vývoje objektu, jak je obsažen v pojmu. Posoudit, zda obsah pojmu není za stupněm rozvoje objektu. Jde o úkol objasnit proces tvorby „,genetické struktury“ objektu, odhalit jeho rozpornost a vývoj.

Empirický sociologický výzkum je v této souvislosti třeba chápat jako nástroj obsahové konkretizace pojmů. Prostřednictvím analýzy faktického materiálu relevantního pojmům dané teorie jsou vytvářeny předpoklady jejich konkretizace.

\section{TEORIE JAKO CIL SOCIOLOGICKËHO ZKOUMÁNÍ SPOLEČENSKÝCH PROCESƯ}

V souvislosti s výše diskutovanou otázkou úlohy logické metody v sociologii je třeba blíže objasnit samotný cíl sociologického výzkumu. ${ }^{9}$ ) $\mathrm{Z}$ výše uvedeného je domnívám se také zřejmé, že cíl výzkumu nelze omezovat jen na vlastní problém verifikace (či falzifikace) stanovených hypotéz. Na výzkum je nutno nahlížet jako na součást poznávacího procesu. $\mathrm{V}$ projektech sociologických výzkumů bývají cíle formulovány zpravidla takto: „zjistit“, „objasnit“, ,prohloubit", „odhalit“, „popsat" apod. něco o zkoumaném jevu.

Kdybychom vyšli z formy výstupů ze sociologických výzkumů, s nimiž se v praxi setkáváme, bylo by moǔné konstatovat, že sociologický výzkum usiluje o 1. shromáždění datové báze, vztahující se ke zkoumanému jevu; 2 . formulaci poznatků o struktuře těchto dat; 3 . formulaci poznatků o vzájemných vztazích mezi různými vlastnostmi zkoumaných objektů; 4. poznatky o faktorech (podmínkách) ovlivňujících určité vlastnosti, stav, souvislosti; 5. shrnutí zobecňujících závěrů. Zpravidla $\mathrm{v}$ těchto podobách jsou výsledné informace obsaženy v závěrečných zprávách výzkumu. Domnívám se, že tyto formy sociologických poznatků nejsou zcela optimální zejména pro jejich využívání v ř́idicí praxi. Mají často nejen nepřehledný charakter, ale především jsou značně parciální, shrnující závěry neodhalují komplexní, podstatné souvislosti, ale zpravidla jsou jen verbálním opisem ostatních forem sociologické informace. $\mathrm{Z}$ toho podle mého soudu vyplývá nezbytnost upřesnit obecné cíle sociologických výzkumů. Nejde jen o shromáždění dat, poznatků o jejich struktuře a vzájemné souvislosti. Hlavním cílem sociologických výzkumů všech druhů je odhalení a formulace $\mathrm{z}$ á $\mathrm{k}$ o $\mathrm{n}$ a příslušného předmětu (problému). Poznání zákonitosti existence jakéhokoliv předmětu (problém, jevu, procesu) je předpokladem pro optimální vstup tohoto poznatku do řídicí praxe. Poznaná zákonitost umožňuje explikaci

${ }^{9}$ ) Mám zde na mysli hlavně sociologický výzkum s použitím metod sběru a vyhodnocení èmpirických dat, aniž tím chci sociologický výzkum omezovat jen na tento typ. 
(vzniká v důsledku explikace) a především také obsahuje racionální možnosti optimálního řešení sociálních problémů, sociální plánování a řízení. Dosavadní praxe sociologického zkoumání zpravidla neobsahuje, a ani o to př́liš neusiluje, formulaci př́ślušného zákona. Takovýto cíl nebývá vůbec kladen. Výzkumníci - sociologové se spokojují s obsáhlým opisem zkoumaného jevu. Tento stav je podle mého soudu důsledkem zmíněného rutinérství v oblasti provádění empirických sociologických výzkumů, šablonovitosti a přecenění technických a metodických činností na úkor využívání výše uvedených teoretických a metodologických postupů. Výzkumníci i metodologové se př́liš zaměstnávají formalizací a standardizací jednotlivých kroků, vytvářením různých schémat, prostředků kvantifikace apod. Naproti tomu nevěnují adekvátní pozornost pojmové analýze relevantní teorie výzkumného úkolu. Jestliže mají být sociologickým výzkumem odhaleny zákonitosti příslušného systému, musí být zkoumány také její obecnější souvislosti, podmínky platnosti a fungování, jinými slovy př́slušný zákon musí být formulován v intencích širší teoretické osnovy. $\mathrm{Tj}$. musí být součástí určité teorie, která postihuje zákonitosti existence, fungování a vývoje vy̌šsích (složitějších) sociálních celků, jichž je zkoumaný systém (jev, předmět) organickou součástí.

Vědecké poznání směřuje tedy $\mathrm{k}$ odhalení zákona, nikoliv $\mathrm{k}$ pouhému popisu struktury, či souvislostí. Co je však zákon, jak jej chápat? V. I. Lenin uvádí ve svých Filozofických sešitech zajímavé charakteristiky a vymezení zákona. „Zákon je trvající (zůstávající) v jevu. (Zákon je identické v jevu). „Zákon = = klidový odraz jevu NB“. „Zákon je odraz podstatného.v pohybu univerza“ “. ${ }^{10}$ ) Poznané vědecky formulované zákony objektívního světa jsou prá vě pro svoji podstatnost, relativní klidovost a stálost důležitým nástrojem řízení společenských procesů. Představují určitý koncentrát našich poznatků o světě a jsou základními stavebními kameny vědeckých teorií.

Problém zákona $v$ metodologii věd je značně komplikovaný a má řadu nedořešených souvislostí. Pro naše potřeby, tj. pro objasnění zákona jako výsledku (cíle) sociologických výzkumů je důležité rozlišení typů zákonů. V. Cerník ve své práci „Problémy zákona v marxistickej metodológii vied“ rozlišuje tři základní stupně vývoje vědeckého zákona: 1 . zákon jevu (resp. faktuální zákon); 2. idealizovaný zákon; 3. imanentní zákon konkrétních celků. ${ }^{11}$ ) Tyto stupně formování vědeckého zákona představují současně relativně samostatné typy odhalení všeobecného $\mathrm{v}$ přírodě a ve společnosti.

$\left.{ }^{10}\right)$ V. I. Lenin: Filozofické sešity. Praha, SNPL 1953, s. 122-123.

11) Viz V. Cerník: Problémy zákona v marxistickej ideológii vied. Bratislava 1977, s. 26. $V$ literatuře se setkáváme $s$ dalšími způsoby členění zákonů. (Viz např. A. K. Uledov: Sociologičeskije zakony. Mysl 1975.) - Pojetí V. Cerníka však skýtá určité výhody ve vztahu k struktuře sociologického poznávání, i když je možné předpokládat jeho postupnou konkretizaci a upřesňování. 
Zákon jevu je nejjednodušším zákonem, je na úrovni zobecnění běžného poznání lidské praxe. Je abstrakcí pouze od náhodných okolností, plynoucí z místa a času průběhu (začátečných podmínek existence jevu). Zákon jevu zachycuje totožné $v$ jevech, ale neztotožňuje se $s$ nimi, tj. nevyčerpává jevy, které jsou jím zobrazovány. Je možno jej ztotožnit $s$ klasifikačním zákonem. ${ }^{12}$ ) To znamená, že se jím identifikuje to, co je společné $v$ jevech. Výsledkem je určité uspořádání jevi̊. Aplikace tohoto zákona $\mathrm{v}$ sociologickém výzkumu představuje tzv. třídění zjištěných dat. Gnoseologická hodnota těchto zákonů je ovšem poměrně malá, umožňuje vytvářet typy jevů v prŕípadě jejich hromadného výskytu a je předpokladem tvorby idealizačních pojmů (abstrakcí). Malá poznávací hodnota zákona jevu vystupuje zvlášsě při zkoumání složitých sociálních celků. Následuje za ní proto nezbytně hledání dalších, hlubších zákonů.

Idealizační zákon je právě tímto hlubším typem zákona, abstrahuje nejen od proměnných podmínek času a prostoru, ale i od tzv. modifikačních podmínek, jež odlišují relativně samostatné celky od dalších podobných celků. Zatímco zákon jevu je schopen do určité míry postihnout rozdíly mezi individui (elementy), pak idealizační zákony odhalují navíc vztahy celků jak uvnitř, tak vztahy $\mathrm{k}$ celkům jiným. Idealizační zákon celku tak již není možno stanovit na základě tř́ídění jevů, ale hledáním vztahů mezi nimi a koncipováním předběžného pojmu. Nástrojem hledání idealizačního zákona je především vztahová analýza. Stanovit vztahový zákon (Filkorn) znamená najít mezi množstvím různých vztahů takové, které charakterizují podstatu celku. Stručně řečeno, podstata idealizovaného zákona nějakého objektu znamená redukci jevové formy na jeho podstatu. Jde tedy o redukci složitého jevu na jeho podstatu. Tyto abstrakce - idealizované zákony, mají v sociologickém poznání své místo. Idealizované zákony umožňují nejen rozlišení jevů, ale i jejich podstat, umožňují identifikaci „vyšších" celků, složitějších systémů v sociálním organismu společnosti a jejich pojmenování. Př́íladem idealizačního zákona je pojem „vrstva“. Představuje abstrakci odlišující určitý sociální objekt od podobných objektů. Nepostihuje však přičinnost existence tohoto objektu, (pouze jej odlišuje od ostatních) a nepostihuje jeho rozpornost a vývoj.

Postihnout vývoj mohou jen imanentní zákony sociálních celkủ. Jde o zákony, které určují nejen fakt existence a souvislosti nějakého sociálního (či jiného) celku, ale také jeho vznik, vývoj i zánik. „Imanentní zákon konkrétních celků je rozporným vztahem jejich podstat, nebo vztahem mezi podstatami.“‘13) Takto vymezený imanentní zákon je fakticky cílem celého procesu poznání př́slušného předmětu vědeckého zájmu. Sociologický výzkum se proto nemůže

${ }^{-12}$ ) Viz V. Filkorn: Úvod do metodológie vied. Bratislava 1960, s. 286.

13) Viz V. I. Lenin: Spisy sv. 38, s. 161. 
omezovat na pouhé třídění (hledání zákonu jevu), či jednoduchou abstrakci při hledání, rozlišování a pojmenování relativně samostatných sociálních celků, Tím, že nějaký celek ve společnosti identifikujeme, popíšeme a pojmenujeme, ještě neznamená, že jsme pochopili jeho funkci, místo a vývoj v rámci celého společenského systému. $\mathrm{K}$ tomu je nezbytné odhalit a formulovat zákon jeho vývoje - jeho imanentní zákon. Pokládám za důležitý krok, při zkvalitňování badatelské práce v sociologii a sociologickém výzkumu, formulování cílů zaměřených právě na odhalování imanentních zákonů vývoje společenských celků.

V této souvislosti vyvstává ještě jeden vážný problém. Ve výše uvedené úvaze předpokládáme, že předmět sociologického zkoumání tvoří relativně samostatný celek. Při každém empirickém výzkumu je však třeba klást otázku, zda předmět výzkumu. je skutečně organickou (systémovou) součâstí celé společenské totality. Zda při jeho stanovení v procesu výzkumu nebyly porušeny dialekticko-logické principy jeho geneze, fungování a vývoje. Zda jde skutečně o „celostní systém“, či pouze jen o náhodně vymezenou část reality. Proto celý výzkumný proces, včetně uplatnění logické metody je současně procesem ověrujuícím a zdůvodňujícím míru „celostnosti“ př́íslušného předmětu zkoumání, a to včetně jeho vztahů $\mathrm{k}$ dalším sociálním celkům. To má rovněž vážné důsledky na procesy abstrahování od podmínek existence celku, a to ve všech fázích výzkumu.

Cílem výzkumu je odhalení imanentního zákona existence celku, jeho podstaty a vztahu této podstaty $\mathrm{k}$ imanentním zákonům celků ostatních. Tedy paralelně jde o proces identifikace tohoto celku a o proces tvorby teorie příslušného celku, jež obsahuje zdůvodněné výpovědi o jeho vztazích $\mathrm{k}$ sociálnímu okolí.

Je zřejmé, že k splnění takovýchto náročných úkolů bádání nepostačí odhalovat pouze zákony jevu, či abstraktní - idealizované zákony, ale že tyto cíle jsou dosažitelné jen důsledným rozvojem teoretické práce s uplatněním logické metody. Také $v$ tomto ohledu nemá však naše současná sociologie dostatečně rozvinutnou metodologii, a tím ani dostatek potřebných zkušeností.

\section{VÝZNAM TEORIE PRO PRÁCI A STANOVENÍ PŘEDMĚTU SOCIOLOGICKEHO VÝZKUMU}

Uvažujeme-li o významu teorie v sociologickém výzkumu, je dále nutné všimnout si stručně problematiky vztahu předmětu a metody: Domnívám se, že správné objasnění tohoto vztahu má i velmi praktické důsledky. Není zajisté potřeba zdůvodňovat, že výsledky sociologického zkoumání společenských jevů mají být využitelné ve společenské praxi. Tato využitelnost však nemusí být 
vždy bezprostřední - přímá. Vstup sociologické informace do společenské praxe a zejména do řídicího rozhodování je velmi složitý. Plyne to ze specifiky této informace, a to jak co do obsahu, tak co do formy. Komplikace také vznikají v důsledku malé připravenosti řídicích kádrů takovouto informaci přijímat a využívat. Cesty vstupu sociologického poznání do praxe jsou proto většinou nepřimé. Jsou komplementární v systému ostatních sociálnị́ch informací o řízeném systému. Současně je možno říci, že čím obecnější charakter tyto informace mají, tím více roste jejich význam jako syntetizujícího základu pro ostatní zdroje a druhy sociálních informací. Předpokladem pro syntetizující obsah obecné sociologické informace je její konstituování na bázi metodologie materialistické dialektiky. Vyplývá to $\mathrm{z}$ faktu, že tato metodologie je rovněž základní a úrčující pro nejobecnější sociologickou teorii - historický materialismus. Tato teorie existující v jednotě s dialektickým materialismem je východiskem i nástrojem všech sociálních výzkumů i základní teoretickou koncepcí řízení všech sociálně ekonomických a sociálně politických procesů v socialistické společnosti. Tato teoretická koncepce nenı uzavřená, naopak představuje živý systém vědeckého poznání, jež je ověřován v praxi, v konkrétní historické aktivitě lidí.

Proces zobecňování sociologických poznatků o této praxi, který probíhá na základě obecné teorie marxistické sociologie, je současně procesem integrace dalších zdrojů sociálního poznání. Nejde již jen o abstrakci sociologických dat a sociologických poznatků, jejichž původ je $\mathrm{v}$ záměrně provedeném empirickém výzkumu, ale jde o zobecňování s využitím dalších, většinou nesociologických poznatkových zdrojů, i zdrojů zkušenostního charakteru. Je možno říci, že prá vě v této integrující roli v procesu zobecňování v marxistické sociologii spočívá také její praktický politický význam.

Předmět sociologického výzkumu nelze proto chápat izolovaně. Nelze přeceňovat a absolutizovat omezující podmínky při jeho empirickém popisu. Tato omezení znemožňují, nebo alespoň značně komplikují využití poznatků v procesu zobecn̆́ování a zakládají tak již faktickou ,izolovanost“ sociologických výzkumů a jimi shromážděných poznatků od ostatních sociálních informačních zdrojů. Komplikují i zobecňovací procesy sociálního poznání a vytvářejí podklady k prohlubování roztržky mezi obecnou marxistickou sociologickou teorií a empirickým výzkumem. Tím je podle mého soudu oṿlivněno i dosud omezené fungování marxistické sociologie jako integrační disciplíny v soustavě sociálního výzkumu. Př́ičiny této situace jsou zjevně také v tom, že sama nejobecnější teorie marxistické sociologie - historický materialismus, není pro potřeby sociologických výzkumů dostatečně rozpracován. Tato rozpracovanost se omezuje na formulaci základních metodologických principů, jež mají být dodržovány při výběru, popisu, analýze atd. objektů konkrétních sociologických 
výzkumů. Význam těchto principů je možné však docenit jen v jejich faktickém využití při rozpracování teoretické koncepce zkoumaného jevu, při jeho analýze, při vymezování jeho souvislostí se širším sociálním okolím, tedy při jeho identifikaci. Což vše předpokládá také obsahové rozpracování obecné teorie, tedy významovou, funkcionální, vztahovou analýzu základních pojmů, kategorií a zákonů této teorie, adekvátní zkoumanému konkrétnímu problému.

$V$ této souvislosti je zejména nezbytné ujasnit si, co je vlastně předmětem sociologického výzkumu. Vymezení není zdaleka jednoduché. Již v předcházejících řádcích této statě se setkáváme s různými označeními pro předmět sociologického výzkumu. (Např. jev, proces, problém, předmět, celek, ale bylo by možno uvést i objekt, systém, zákonitost, stav apod.) Přitom všechny tyto pojmy jsou $v$ té či oné souvislosti relevantní. Co se tedy sociologickým výzkumem vlastně zkoumá?

Odpověd' na tuto otázku je třeba hledat $\mathrm{v}$ rozboru vědecké práce jako specifické lidské činnosti. Lidský čin je dialektickou jednotou jeho prvků, tj. cíle, prostředku, předmětu a výsledku. ${ }^{14}$ ) Vědecká práce je složitý proces, jež v každém svém kroku obsahuje různé specifické činnosti, v nichž subjekt zkoumání prostřednictvím určitých metod (prostředků) „opracovává“" předmět svého zájmu s cílem dosažení určitých poznatků. Výsledkem vědecké práce je tedy poznatek, který má různou podobu, různý stupeň pravdivosti, ,dokonalosti“ “, různou formu. Výsledek závisí do značné míry na cíli, jež si subjekt poznání klade. Cíl musí být adekvátní dosaženému stupni poznání, přiměřený metodám, jež jsou $\mathrm{k}$ dispozici a především adekvátní samostatnému předmětu. $Z$ naznačeného je zřejmé, že jednotlivé složky lidské činnosti obecně a vědecké poznávací činnosti zvlášt' se vzájemně podmiňují, že spolu tvoří dialektický celek. Nelze tedy jednoznačně tvrdit, že cíl výzkumu je určen jen předmětem, nebot' musíme brát v úvahu stav metodických prostředků, stejně tak nelze tvrdit, že předmět určuje metody, nebot' metody jsou rovněž určovány cílem. Stejně tak nelze tvrdit, že cíl je určen předmětem, nebot' zde hrají roli nejen disponsibilní metody, ale i dosažený stupeň poznání (teorie) předmětu a dosažený stupeň poznání reality vůbec. Proto jako předmět mohou vystupovat v závislosti na cíli (jež sám je determinován jak předmětem, tak širšími souvislostmi, společenskou potřebou) a metodách různé stránky sociální reality. $K$ této složité dialektice patří ještě skutečnost, že předmět, cíl, prostředky, metody se vyvíjejí. jako relativně samostatné systémy $\mathrm{v}$ procesu poznání.

Zdrojem samovývoje předmětu jako nedílné součásti objektivní reality je především sama rozpornost jeho složek a jen zprostředkovaně se zde projevují i vlivy jejich poznávání. Tato zprostředkovanost působení poznání na vývoj

${ }^{14}$ ) Viz V. Seiler: Štruktúra ludského činu. Bratislava, Pravda 1974, s. 12. 
předmětu sociálního výzkumu je realizovaná hlavně ř́ícími aktivitami. Zdrojem vývoje prostř̌edků poznávání ve vědě je především sama poznávací činnost, daná rozporností mezi adekvátností metod poznání a vlastním vývojem předmětu zkoumání, nebo sociálním celkem. Také cíl výzkumu prodělává neustálý dynamický vývoj, a to v závislosti jak na změně předmětu samotného, tảk, a to především, na dynamice rozporů mezi sociální praxí a poznáním této praxe vyjádřené potřebou poznatků pro uvědomělou řídicí aktivitu. Zejména tento moment je důležitý pro určení obsahu sociologického výzkumu.

Sociologové často nedoceňují ve své praktické výzkumné práci tuto složitou dialektiku mezi předmětem a cílem výzkumu. Tím méně pak dialektiku jejich vlastního vývoje. Svědčí o tom opakování výzkumů na stejné téma, rutinérství v používaných metodách (většinou jde jen o prostředky popisu vlastností strukturních prvků sociálních objektů, tj. dotazník, anketa a dále tř́íění dat a následná vztahová, v lepším případě faktorová analýza). Toto rutinérství v oblasti metod, cílů a vymezení předmětu výzkumu často vede až $\mathrm{k}$ redukci pojetí předmětu samotné marxistické sociologie na zkoumání struktur názorů, postojů, mínění, či na struktury vlastností sociálních objektů, tedy na jakousi specifickou sociální statistiku. Převažujícízaměření sociologického výzkumu na popis sociální reality vede pak některé autory, zvláště nesociology $\mathrm{k}$ redukci marxistické sociologie jen na sociologický výzkum. Tím se jen dále prohlubují problémy spojení empirického poznávání sociálních jevů s teoretickými disciplínami v rámci marxismu-leninismu, potlačuje se integrační a syntetizující funkce obecné marxistické teorie. Současně se tím vytváří iluze o možnostech převážně jen induktivních zdrojů pro vytvoření nové obecné sociologické teorie mimo její nejvyšší rovinu obecnosti. Specifickým způsobem se v takového praxi provádění sociologických výzkumů znovu projevují rysy empirismu, jenž byl podroben metodologické kritice u nás již na počátku sedmdesátých let. Empirismus sám o sobě nemá zpravidla dlouhou platnost a ve vztahu k společenské praxi musí být překonán vytvářením obecnějších a zobecňujících koncepcí. Vytváří se jím však prostor pro pronikání nemarxistických teoretických koncepcí společnosti, které někdy pak slouží jako báze pro interpretaci empiricky shromážděných poznatko̊.

Shrneme-li diskusi o problému vztahu mezi předmětem, cílem, metodou a teorií v sociologickém bádání, je možno uvést, že nerespektování vzájemné podmíněnosti i vnitřní dialektiky těchto složek vědecké činnosti vede $\mathrm{k}$ zaostávání sociologické badatelnosti práce za potřebami společenské praxe. Na straně druhé pak naopak vede $\mathrm{k}$ přeceňování specifiky této vědy a nedocenění jejího integračního a syntetizujícího poslání v rámci systému marxistických společenských věd. 


\title{
К ВОПРОСУ О РОЛИ ТЕОРИИ В СОЦИОЛОГИЧЕСКИХ ИССЛЕДОВАНИЯХ
}

\author{
Pезюме
}

В данной статье рассматриваются некоторые аспекты роли теории в процессе социологических исследований. Подчеркивается значение развития теории при подготовке и проведении социологических исследований.

Автор дает краткую характеристику состояния теории социологии и указывает на недостатки, имеющиеся в этой области в чехословацкой социологии.

В первой части работы дискутируется вопрос значения логического метода для теоретического анализа изучаемой проблемы, объяснения понятий и их постепенного уточнения.

Во второй части автор рассматривает вопрос целей социологических исследований. Указывается, что целью исследования необходимо считать открытие определенного закона изучаемого целого. Для практического использования социологических познаний недостаточно просто описать свойства, структуру и взаимосвязи. Поэтому вкратце приводятся типы законов, познаваемых и формулируемых в процессе социологической исследовательской деятельности.

В третьей части автор стремится показать значение уяснения связи между предметом, целью, методом и теорией исследований. Он указывает на их взаимообусловленность и противоречивость их развития в связи с характером исходной точки социологических исследований. Одновременно подчеркивается интеграционная и синтезируюшая функция марксистской социологии.

\section{ZUR ROLLE DER THEORIE IN DER SOZIOLOGISCHEN FORSCHUNG .}

\section{Zus a m m e f a s u n g}

In der Studie werden einige Aspekte der Rolle der Theorie im Prozeß der soziologischen Forschung erörtert. Betont wird da die Bedeutung der Entfaltung der Theorie bei der Vorbereitung und Durchführung soziologischer Forschungen. Es wird hier eine kurze Charakteristik des Entwicklungsstandes der soziologischen Theorie dargelegt sowie die Mängel, die in dieser Sphäre der tschechoslowakischen Soziologie anzutreffen sind.

Im ersten Teil wird die Frage der Bedeutung der logischen Methode für die theoretische Analyse des zu erforschenden Problems dikutiert, für die Erläuterung von Begriffen und deren stufenweisen Präzisierung.

Im zweiten Teil wird die Frage der Ziele der soziologischen Forschung erörtert. Es wird dargelegt, daß die Entdeckung eines bestimmten Gesetzes der zu erforschenden Entität als Forschungsziel zu betrachten ist. Für eine praktische Anwendung des soziologischen Eṛkennens reicht nicht eine bloße Beschreibung von Eigenschaften, ihrer Struktur und ihrer gegenseitigen Beziehungen. Aus dem Grunde werden Typen von Gesetzen kurz abgerissen, die im Prozeß der soziologischen und Forschungsarbeit erkannt und formuliert werden.

Der dritte Teil ist der Bedeutung der Erläuterung von Beziehungen zwischen Forschungsobjekt, -ziel, -methode und -theorie gewidmet. Es werden ihre gegenseitige Bedingtheit und Widersprüchlichkeit ihrer Entwicklung bezüglich des Charakters des Ausgangs der soziologischen Forschung dargelegt. In diesem Zusammenhang wird die integrierende und synthetisierende Funktion der marxistischen Soziologie betont. 